\title{
Perkután transzkoronáriás septalis myocardium ablatio (PTSMA) hipertrófiás cardiomyopathiában: hosszú távú utánkövetés eredményei
}

\author{
Szúcsborus Tamás', Pálinkás Attila², Nagy Viktória', Pálinkás Eszter', \\ Ungi Imre', Hubert Seggewiss ${ }^{3}$, Sepp Róbert'
}

\author{
${ }^{1}$ Szegedi Tudományegyetem, II. sz. Belgyógyászati Klinika és Kardiológiai Központ, Szeged \\ ²Erzsébet Kórház, Belgyógyászati Osztály, Hódmezővásárhely \\ ${ }^{3}$ Medizinische Klinik 1, Leopoldina-Krankenhaus, Schweinfurt, Németország
}

Levelezési cím: Dr. Sepp Róbert, Szegedi Tudományegyetem, II. sz. Belgyógyászati Klinika és Kardiológiai Központ, 6725 Szeged, Semmelweis u 8. E-mail: sepprobert@gmail.com

\begin{abstract}
Háttér: A perkután transzkoronáriás septalis myocardium ablatio (PTSMA) a bal kamra kifolyótraktus csúcsgradiens csökkentésére kifejlesztett eljárás obstruktív hipertrófiás cardiomyopathiában (HCM).

Célkitűzés: Célunk az volt, hogy klinikánkon PTSMA-n átesett betegek hosszú távú utánkövetési adatait elemezzük.

Betegek és módszerek: 2005 márciusa és 2017 decembere között 55 betegben végeztünk kontraszt echokardiográfia vezérelt PTSMA-t. Huszonhárom esetben a beavatkozás feladására kényszerültünk, mert a kontraszt echokardiográfia abnormis kollaterálisok által ellátott szívizomterületeket igazolt. A 32 elvégzett esetben (19 nő, 13 férfi, átlagéletkor $51 \pm 14$ év) 3 és 12 hónapos kontrollra került sor teljes körü kardiális felméréssel.

Eredmények: Haláleset, major aritmia, végleges PM-implantációt igénylő AV-blokk nem történt a beavatkozások és az utánkövetés alatt. A betegek NYHA-stádiuma szignifikánsan javult mind a 3 hónapos kontrollkor ( $p<0,0001)$, mind a 12 hónapos kontrollkor ( $p=0,0008)$. A beavatkozás után 13 esetben alakult ki szárblokk (típusosan RBBB), amely a 12 hónapos kontrollkor is megmaradt. Az echokardiográfiával meghatározott nyugalmi bal kamrai kifolyótraktus (LVOT) csúcsgradiens szignifikánsan csökkent mind a háromhónapos $(80 \pm 33$ vs. $40 \pm 46 \mathrm{Hgmm}, \mathrm{p}=0,0099)$ mind az egyéves utánkövetéskor $(75 \pm 38$ vs. $37 \pm 31$ $\mathrm{Hgmm}, p=0,039$ ), a provokált gradienshez hasonlóan (3 hónap: $124 \pm 44$ vs. $57 \pm 55 \mathrm{Hgmm}, p=0,0016 ; 12$ hónap: $136 \pm 45$ vs. $81 \pm 61 \mathrm{Hgmm} p=0,0469)$. Az átlagosan $5 \pm 3$ éves utánkövetés alatt haláleset a betegcsoportban nem történt.

Összefoglalás: A perkután transzkoronáriás septalis myocardium ablatio rövid és hosszú távon is hatásosan csökkenti mind a nyugalmi mind a terhelés indukálta bal kamrai kifolyótraktus gradienst, amellyel egyidejüleg a betegek klinikai tünetei is kifejezett javulást mutatnak.
\end{abstract}

Kulcsszavak: hipertrófiás cardiomyopathia, perkután transzkoronáriás septalis myocardium ablatio, kontraszt echokardiográfia

Percutaneous transcoronary septal myocardial ablation (PTSMA) in hypertrophic cardiomyopathy: results of longterm follow up

Background: Percutaneous transcoronary septal myocardium ablation (PTSMA) is a catheter-based method to relieve the left ventricular outflow tract (LVOT) obstruction in hypertrophic cardiomyopathy (HCM).

Aims: We aimed to analyze the long-term follow-up data of our patients underwent PTSMA at our Department.

Patients and methods: Between March 2005 and December 2017 contrast echocardiography guided PTSMA was performed in 55 patients. In 23 cases, PTSMA was given up due to abnormal collaterals perfusing non-target myocardial areas. In the 32 completed cases (19 females, 13 males, average age $51 \pm 14$ yrs) follow up with complete cardiology assessment was performed at 3 and 12 months.

Results: No patient had death, major arrhythmia, newly developed AV or bundle branch block, requiring permanent pace-maker implantation during the procedures or follow-up. NYHA status of the patients was significantly improved both at 3-month $(\mathrm{P}<0.0001)$, and one-year follow up $(\mathrm{P}=0.0008)$. The resting peak LVOT gradient decreased significantly both at 3-month $\mathrm{FU}$ ( $80 \pm 33$ vs. $40 \pm 46 \mathrm{mmHg}, \mathrm{P}=0.0099)$ and at one-year $\mathrm{FU}(75 \pm 38$ vs. $37 \pm 31 \mathrm{mmHg}, \mathrm{P}=0.039)$. The provoked gradient was also substantially decreased (at 3 -month FU: $124 \pm 44$ vs. $57 \pm 55 \mathrm{mmHg}, \mathrm{P}=0.0016$; at $12-\mathrm{month} \mathrm{FU}: 136 \pm 45 \mathrm{vs}$. $81 \pm 61 \mathrm{mmHg}$ $\mathrm{P}=0.0469$ ). All the patients were alive during the average $5 \pm 3$ years-long follow up.

Conclusion: Percutaneous transluminal septal myocardium ablation is a powerful method to decrease left ventricular outflow tract obstruction in hypertrophic cardiomyopathy. The procedure is effective also on the long term and subsequently leads to improvement of symptoms and exercise capacity of the patients.

Keywords: hypertrophic cardiomyopathy, percutaneous transcoronary septal myocardium ablation, contrast echocardiography 


\section{Bevezetés}

A hipertrófiás cardiomyopathia (HCM) kifejezett szivizom-hipertrófiával jellemzett primer myocardiumbetegség, amely típusosan a sarcomer fehérjéit kódoló gének mutációja következtében alakul ki (1). A HCM fenokópiák formájában, úm. amyloidosis (2), Danon-betegség (3), Fabry-kór (4) is megjelenhet, illetve egyes ioncsatorna-betegségek által okozott szisztémás kórképek (5) részjelensége is lehet.

A HCM-es betegek mintegy $25 \%$-ában nyugalomban, további mintegy $40 \%$-ában provokáció hatására nyomásgradiens detektálható a bal kamra és az aortabillentyü között, a bal kamrai kifolyótraktusban, amely alapján hipertrófiás obsrtuktív cardiomyopathia (HOCM) csoportot képez. A nyomásgradiens a mitrális billentyű anterior vitorlájának elöremozdulása (systolic anterior motion, SAM) és a septummal való összeérésének következményeként jön létre a bal kamrai szisztolé során. HOCM-re jellemző hemodinamikai sajátosságok, mint a bal kamrai végdiasztolés nyomás emelkedése, fokozott bal kamrai falfeszülés miatt diasztolés diszfunkció és miokardiális iszkémia jelentkezik. A korábbi HOCM-betegcsoporttal végzett vizsgálatok igazolták a bal kamrai kifolyótraktusban mért nyomásgradiens jelentőségét, prognosztikus értékét (6).

A relatív magas prevalenciával (1:500-1:1000) előforduló betegség gyakran az optimális gyógyszeres kezelés ellenére is jelentős panaszokat okozhat, a számos új terápiás próbálkozás (ACE-gátlók [7], ranolazin [8], MYK-461 [9]) ellenére. Az obstrukcióval rendelkező betegek számára korábban a szívsebészeti myectomia volt az egyetlen kezelési lehetőség, amely során a hipertrofizált septumon végeztek sebészi kimetszést, megszüntetve ezzel a bal kamrai kifolyótraktus nyomásgradiensét. A perkután transzkoronáriás septalis myocardium ablatiót (PTSMA) a 90-es évek közepén fejlesztették ki a bal kamra kifolyótraktus csúcsgradiens csökkentésére obstruktív hipertrófiás cardiomyopathiában (10). Utóbbi során szívkatéteres technikával, etil-alkohol használatával művi infarktust hoznak létre, amely során a septalis területre lokalizált szövetnekrózis után hegszövet alakul ki, amely csökkenti a hipertrófia mértékét, ezáltal a gradiens is megszünik vagy jelentős csökkenése alakul ki. Ezen technika azonnali, rövid- és középtávú eredményei az irodalomban ismertek (11).

$\mathrm{Az}$ első magyarországi alkoholos septum ablatióról Apró és munkatársai számoltak be előadásukban (12), míg kontraszt echokardiográfia vezérelt PTSMA-t munkacsoportunk alkalmazott először Magyarországon (13). Jelen munkánkban célunk az volt, hogy klinikánkon gondozott és PTSMA-val kezelt HOCM-es betegek hosszú távú utánkövetési adatait elemezzük.

\section{Betegek és módszerek}

Betegek

2005 márciusa és 2017 decembere között 55 betegben végeztünk kontraszt echokardiográfia vezérelt PTSMA-t.
Huszonhárom esetben a beavatkozás feladására kényszerültünk, mert a beavatkozás során végzett kontraszt echokardiográfia során (a beavatkozás részletes leírását Id. később) abnormis kollaterálisok által ellátott szívizomterületeket észleltünk. A 32 elvégzett eset közül

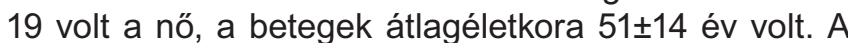
betegek kivizsgálása a Szegedi Tudományegyetem, II. sz. Belgyógyászati Klinika és Kardiológiai Központban történt, standard kivizsgálási protokollok szerint (14, 15). A HOCM diagnózisa és a kezelésig eltelt idő $6,2 \pm 5,6$ év volt. A betegek funkcionális stádiuma a beavatkozás előtt NYHA II-IV. között volt. Echokardiográfiával a maximális balkamra-falvastagság $\left(\mathrm{LV}_{\max }\right)$ értéke $23,7 \pm 5 \mathrm{~mm}$ volt, SAM-jelenség $31 / 32$, syncope $7 / 32$ esetben fordult elő.

A PTSMA indikációját klinikai és/vagy hemodinamikai paramétereik alapján állítottuk fel [New York Heart Association (NYHA) III-IV. stádium, pre-syncope, syncope elöfordulása és/vagy a bal kamrai kifolyótraktusban mért $>50 \mathrm{Hgmm}$ nyugalmi, vagy $>100 \mathrm{Hgmm}$ provokálható (Valsalva-manőver, post-ES-potenciáció, fizikai terhelés) gradiens. Az invazív kardiológiai kivizsgálás részeként koronarográfia történt, a PTSMA-ra alkalmas septalis artéria megítélése céljából. Az utánkövetés során 3 és 12 hónapos kontrollokra került sor teljes körü kardiális felméréssel.

\section{PTSMA kivitelezése}

A beavatkozást szívkatéteres mütőben végeztük, két femoralis artéria és egy femoralis véna kanülálásával. $A$ vénás sheat-en keresztül ideiglenes pacemaker (PM) elektródát pozícionáltunk a jobb kamrában a procedúra lehetséges szövődményeként előforduló ingervezetési blokk kezelésére. A bal kamra csúcsában nyomásmérés céljából egy pigtail katétert pozícionáltunk. $A$ bal koronáriaszájadékot egy standard felvezető katéterrel kanüláltuk, amin keresztül aortás nyomásgörbe elvezethető is volt a szimultán hemodinamikai mérésekhez (nyugalmi és provokálható gradiens mérése a PTSMA előtt és után [1. ábra]). A célterületet ellátó septalis artériába szelektíven $\mathrm{PCl}$-vezetődrótot juttatunk (2. ábra, $A-D$ panelek), majd szubszelektív angiográfiát végezve győződünk meg annak ellátási területéröl és annak pontos izolálásáról. Ezt követően kontraszt echokardiográfiát végeztünk, abnormis kollaterális ágak kizárása céljából. Parasternalis hossz- és rövidtengelyi, csúcsi 3-üregi és subcostális echokardiográfiás síkokból identifikáltuk a septalis ág által ellátott myocardium-területet (3. ábra $A-C$ panelek). Az echokardiográfia során különös figyelmet fordítottunk a septumon kívüli myocardium-területek (papilláris izmok, jobb kamra) esetleges opacifikációjának felismerésére, valamint a septalis kontraszthalmozódás kiterjedésének megítélésére. Az echo-kontrasztanyag által opacifikált myocardium-terület eloszlása alapján döntöttünk a PTSMA kivitelezhetőségéről. A standard képek rögzítése után, PTSMA-ra való alkalmasság esetén az izolált septalis artériába 

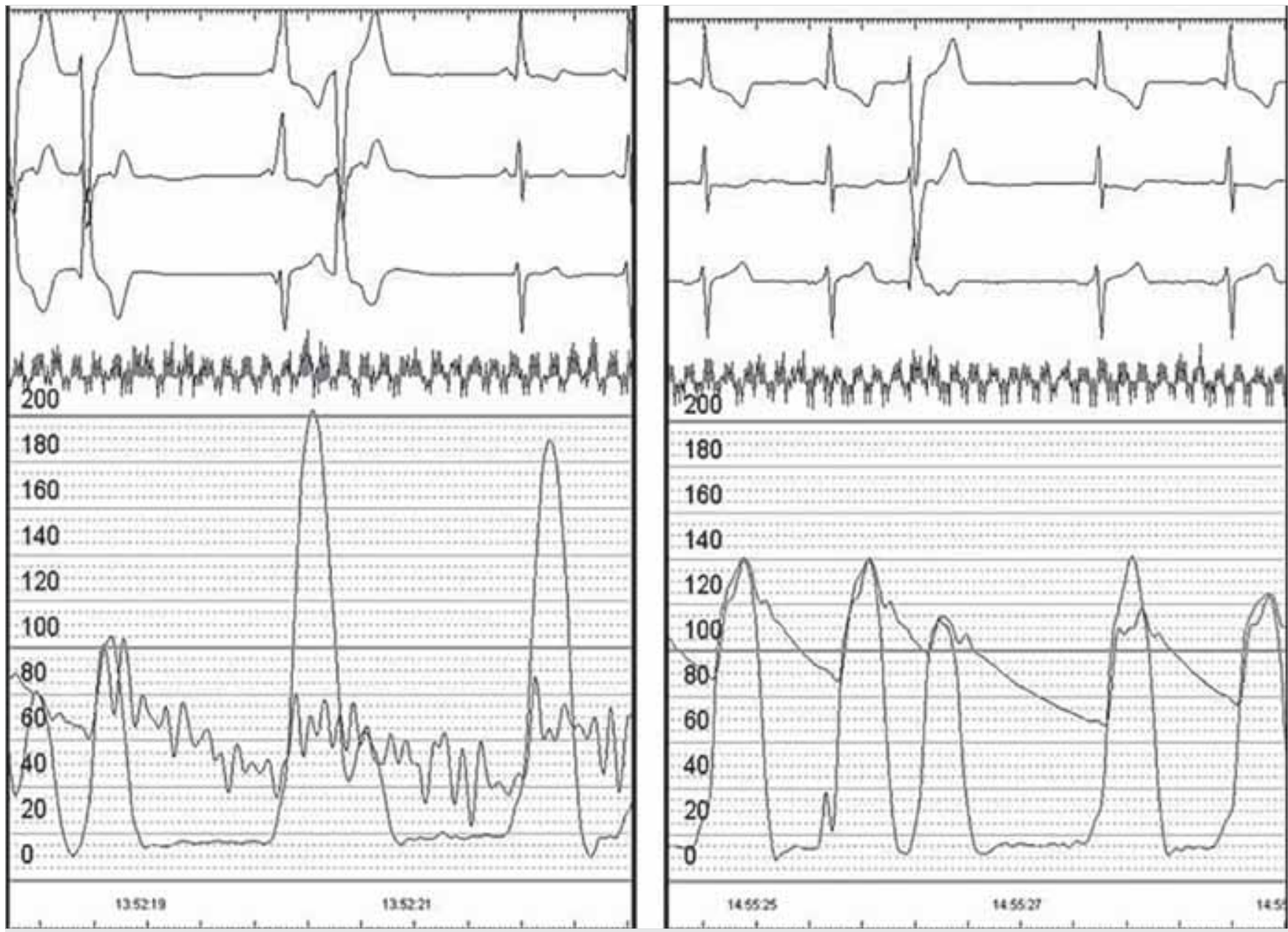

1. ÁBRA. PTSMA során regisztrált nyomásgörbe a bal kamrai kifolyótraktusban szívkatéteres technikával. PTSMA előtt a provokáló extraszisztolé után jelentős, 120 Hgmm nyomásgradiens mérhető (bal oldal), míg a sikeres beavatkozás után a provokált extraszisztolét nyomásgradiens nem követi (jobb oldal)

over-the-wire (OTW) ballonon keresztül 97\%-os tisztaságú abszolút etil-alkoholt juttattunk az ellátott septum vastagságának megfelelő mennyiségben $(1 \mathrm{ml} / 10$ $\mathrm{mm})$. Az OTW-ballon felfújását minimum 10 percig fenntartottuk, amely idő elegendő a beadott alkohol felszívódásához, kontrollált infarktus létrehozásához. Az OTW-ballon eltávolítását követően kontroll angiográfia történt a septalis artéria elzárása igazolására és további érsérülés kizárása céljából. A betegek további obszervációra a koronáriaőrzőben kerültek 48 órára. Az ideiglenes PM-elektróda 24 óra elteltével AV-blokk hiányában eltávolításra került. Az ablatio hatására kialakuló nekroenzimszint követése 48-72 óráig történt.

\section{Eredmények}

Procedurális eredmények

A beavatkozásra került 55 beteg közül huszonhárom esetben a beavatkozás feladására kényszerültünk, mert a beavatkozás során végzett kontraszt echokardiográfia során abnormis kollaterálisok által ellátott szívizomterületeket észleltünk. Utóbbi esetekben a kontraszt echokardiográfia típusosan a tricuspidalis billentyű papilláris izmaiban mutatott halmozódást, de fenti jelenséget a jobb kamra szabad falában, illetve a bal kamra laterális falában is észleltük. Egyes esetekben a septalis ág fejlettsége miatt a septum jelentős része opacifikálódott, jelentős kiterjedésü nekrózis veszélyét vetve fel. Fenti esetekben a beavatkozás feladásra került.

\section{Funkcionális eredmények}

A betegek NYHA-stádiuma szignifikánsan javult mind a 3 hónapos kontrollkor ( $p<0,0001)$, mind a 12 hónapos kontrollkor $(p=0,0008)$. Az elért funkcionális javulás a hosszú távú utánkövetésünk során is megmaradt. A beavatkozás során 13 esetben alakult ki szárblokk (típusosan RBBB), amely a 12 hónapos kontrollkor is megmaradt.

\section{Hemodinamikai eredmények}

Az echokardiográfiával meghatározott nyugalmi bal kamrai kifolyótraktus (LVOT) csúcsgradiens szignifi-

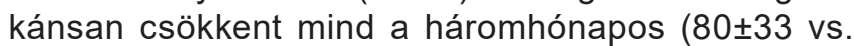




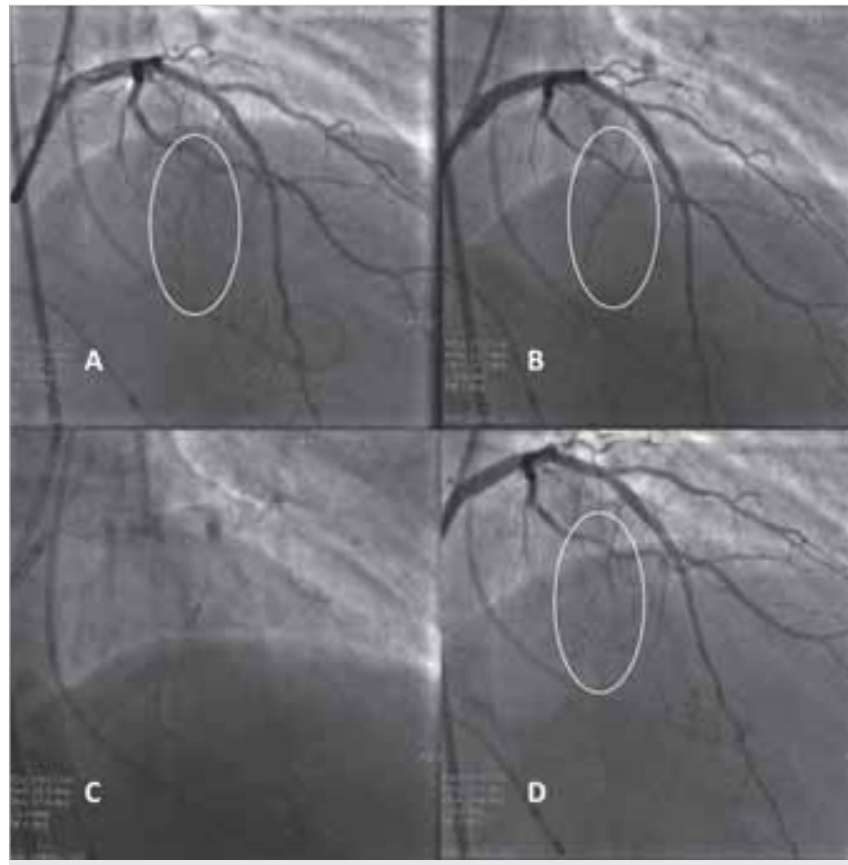

2. ÁBRA. PTSMA technikai kivitelezése. A-panel: több lehetséges septalis artéria drótozása és szelektív töltése. B-panel: cél septalis artéria kiválasztása és echokardiográfiás kontrasztanyaggal való feltöltése. C-panel: OTW-ballonnal a septalis artéria elzárása, festése és az abszolút etil-alkohol beadása. D-panel: Záró angiográfia során a kezelt septalis artéria okklúziója látható, illetve a többi ér épsége

40 $\pm 46 \mathrm{Hgmm}, \mathrm{p}=0,0099)$ mind az egyéves utánkövetéskor ( $75 \pm 38$ vs. $37 \pm 31 \mathrm{Hgmm}, p=0,039)$, a provokált gradienshez hasonlóan (3 hónap: 124 \pm 44 vs. $57 \pm 55$ Hgmm, $p=0,0016$; 12 hónap: $136 \pm 45$ vs. $81 \pm 61$ Hgmm $p=0,0469)$. Az átlagosan $5 \pm 3$ éves (22/32 beteg) utánkövetés alatt haláleset a betegcsoportban nem történt, syncope 1 betegnél fordult elö. A funkcionális stádiumban változás nem volt, a betegek a PTSMA kapcsán elért hemodinamikai javulást megtartották.

\section{Szövődmények}

A beavatkozások során és az utánkövetés alatt haláleset, major aritmia, kardiogén sokk, azonnali cardioversiót igénylő ritmuszavar, végleges PM-implantációt igénylő AV-blokk nem fordult elő. Egy esetben abnormis kollaterális összeköttetés miatt a jobb koronária distalis okklúziója alakult ki, következményes inferior területi nekrózissal. Egy alkalommal késői AV-blokk jelentkezett 36 órával a beavatkozás után, amely miatt az ideiglenes PM-elektróda reimplantálása volt szükséges, azonban végleges PM-implantációra nem volt szükség. Ritmuszavarok közül egy széles QRS-tachycardia (vs. flattern, hemodinamikai megingás nélkül) emelendő ki, ami amiodaron mellett konvertálódott.

\section{Megbeszélés}

Jelen klinikai ajánlások szerint PTSMA azokban a betegekben indikált, akik az optimális gyógyszeres kezelés ellenére sem válnak tünetmentessé és New York Heart Association (NYHA) III-IV., illetve Canadian Cardiac Society (CCS) III. funkcionális stádiumban vannak $(14,15)$. A beavatkozás hemodinamikai kritériuma a SAM következtében kialakuló, szignifikáns mértékü (>50 Hgmm nyugalmi és/vagy >100 Hgmm provokálható), LVOT-gradiens jelenléte. Amennyiben a gradiens mellett más objektív limitáló tényezők, mint pl. ismétlődő terhelés indukálta syncope, terhelésre bekövetkező vérnyomásesés, paroxizmális pitvarfibrilláció igazolható, szelektált esetekben NYHA II. stádiumú betegekben is elvégezhető a beavatkozás. A beavatkozás morfológiai kritériuma a SAM-kontaktus helyén lévő, hipertrofizált septum részt ellátó, megfelelően fejlett septalis ág megléte.

Sikeres PTSMA során a LVOT-gradiens már közvetlenül a beavatkozást követően szignifikáns mértékben csökken, amely remodelling következtében 6-12 hónap múlva éri el végleges mértékét (16-19). A bal kamrai re-

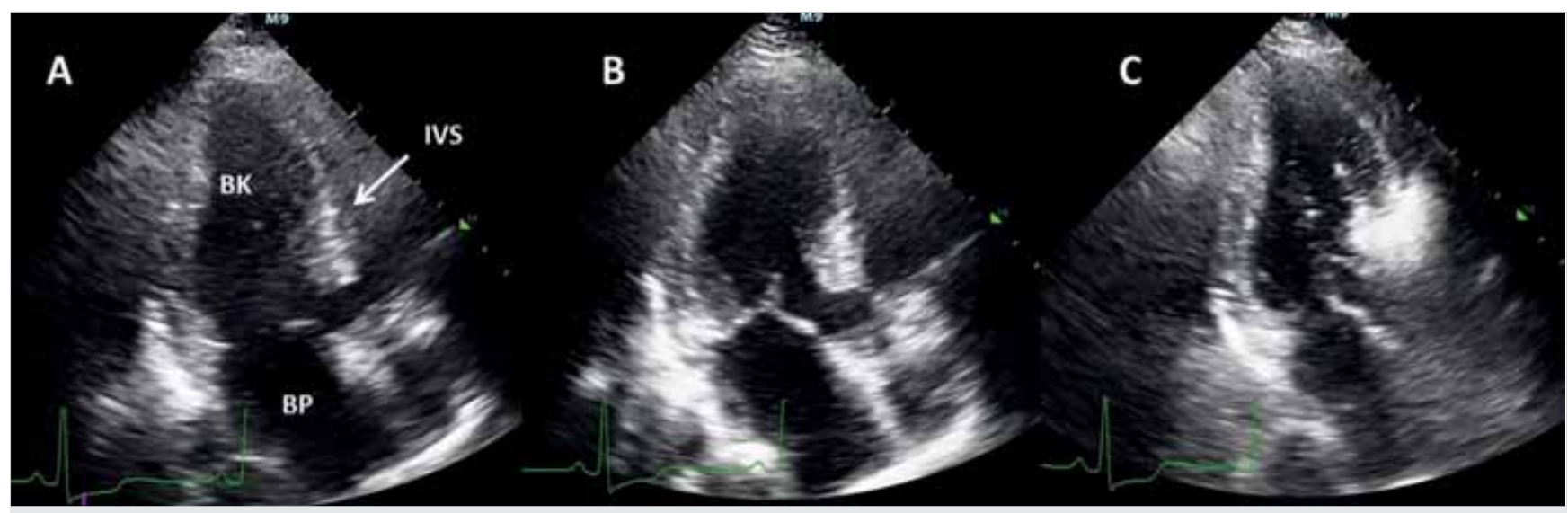

3. ÁBRA. A képen jól látható a septalis túlsúllyal jelentkező hipertrófia (A-panel). Az echokardiográfiás kontrasztanyag beadását követően a septalis artéria ellátási területe jól azonosítható, az echo kontrasztanyag a septum basalis és középső részére lokalizálódik, amely alapján a PTSMA elvégezhető (B- és C-panel). BK: bal kamra, BP: bal pitvar, IVS: intraventricularis septum 
modelling jeleként a bal kamrai hipertrófia regresszióját lehet kimutatni, amely nemcsak az ablált septalis szegmenst, hanem az indukált nekrózistól távolabb eső bal kamrai szegmenseket is érintette (20). A beavatkozás következményeként normalizálódik a bal kamrai végdiasztolés nyomásérték, csökkent a szisztolés túlterhelés. A betegek funkcionális stádiuma szignifikáns mértékben javul, hasonlóképpen futószőnyeg terheléssel, illetve spiroergometriával objektivizálható módon javult terhelhetőségük is $(21,22)$. Eredményeink alátámasztják fenti megfigyeléseket.

A PTSMA technikájának egyik legjelentősebb aspektusa a miokardiális kontraszt echokardiográfia (myocardial contrast echocardiography, MCE) intraoperatív használata. Az MCE segítségével az ablálni kívánt septalis area tökéletesen vizualizálható, s amennyiben adott septalis ágba jutatott kontraszt nem az ablálni kívánt lokalizációban jelenik meg, más septalis ág, esetlegesen atípusosan eredő septalis ág választható az alkohol bejuttatására (23). Amennyiben ilyen septalis ág MCE-vel nem azonosítható, az alkoholos ablatio kontraindikált. Más esetekben kontraszttelődés igazolható MCE-vel az ablálni kívánt septalis területen kívül, úm. a papilláris izmokban, a jobb és/vagy bal kamra szabad falában. Ezekben az esetekben az alkoholos ablatio utóbbi struktúrák nekrózisát is előidézheti, azok minden potenciális szövődményével (szabad kamrafalruptúra, papilláris izomruptúra, akut mitrális/tricuspidális regurgitációval). Értelemszerűen a PTSMA ezekben az esetekben is kontraindikált.

A PTSMA korai és késői klinikai sikerességének prediktoraival több vizsgálat foglalkozott. Chang és munkatársai közlése szerint 173 PTSMA-n átesett beteg közül 39 betegnek nem volt kielégítő az eredménye az első beavatkozás után. A nem kielégítő eredmény prediktorai a magasabb kiinduló LVOT-gradiens, kevesebb ablált septalis ág, alacsonyabb csúcs CK-érték, a kontraszt echokardiográfián látott opacifikált kisebb septalis terület és magasabb reziduális gradiens voltak (24). A tünetek, septalis falvastagság, a mitrális regurgitáció súlyossága, és a BK-funkció nem voltak összefüggésben a kimenetellel. Multivariáns analízissel a 25 Hgmm-nél kisebb gradiens csökkentés és a 1300 U/Lnél kisebb CK-érték voltak a nem kielégítő procedurális kimenetel független prediktorai.

Keren és munkatársai vizsgálatai szerint a nem megfelelő klinikai eredményű betegekben a csúcs CK 500 U/I-nél kisebb volt, és 850 U/I-nél magasabb a sikeres esetekben. Az LVOT-gradiens ismételt mérésével igazolták, hogy az LVOT-gradiens csökkenése a 3. napon $27 \%$-ban, a 7. napon 73\%-ban jósolta meg a kedvező klinikai kimenetelt. A maximális CK-érték és a 7. napon mért LVOT-gradiens alapján négy csoportba voltak a betegek sorolhatók: „korai siker” (alacsony LVOT-gradiens és magas CK, a sikeres esetek 73\%-a), „késői siker” (magas LVOT-gradiens és magas CK), „korai sikertelenség" (alacsony CK, és magas gradiens), illetve „késői sikertelenség” (alacsony CK és alacsony gradiens) (25).

Sorajja és munkatársai publikációja szerint a PTSMA utáni klinikai siker legerősebb prediktorai az idősebb életkor, alacsonyabb LVOT-gradiens, kisebb septumhipertrófia, és kisebb LAD-átmérő voltak. A mitrális billentyű geometria vagy septalis morfológia nem állt öszszefüggésben a kimenetellel. $A \geq 3$ kedvező prediktorral rendelkező betegek ( $\geq 65$ év életkor, <100 Hgmm gradiens, $\leq 18 \mathrm{~mm}$ septalis átmérő, <4,0 mm LAD-átmérő) 4 évvel a beavatkozás utáni klinikai státusza (halál, illetve súlyos tünetektől való mentesség) kedvezőbb volt $(90,4 \%)$, mint a két ilyen kedvező prediktorral $(81,6 \%)$ vagy a $\leq 1$ prediktorral rendelkezőké (57,5\%). Az operátor által elvégzett több mint 50 esetszám szintén a sikeresség független prediktora volt. Az injektált alkohol mennyisége, az injektált ágak száma vagy átmérője nem volt prediktív a klinikai sikerre (26). Jelen elérhető adatok azt igazolják, hogy a HCM-es betegekben meglévő hirtelen szívhalál rizikót (27-29) a PTSMA nem növeli (30).

\section{Következtetések}

Összefoglalva, munkánkban kontraszt echokardiográfiával vezérelt perkután transzkoronáriás septalis myocardium ablatio hosszú távú utánkövetési eredményeit mutattuk be. A beavatkozás az alkalmazott metodika mellett biztonságosan végezhető, és a fennálló LVOT-gradiens tartós és szignifikáns csökkenéséhez vezet HCM-es betegekben.

\section{Köszönetnyilvánítás}

A munka a „Ritka betegségek patogenezisének kutatása, új diagnosztikai és terápiás eljárásokat megalapozó fejlesztések” (GINOP-2.3.2-15-2016-00039) és a „Stay alive" (GINOP-2.3.2-15-2016-00048) támogatásával készült.

\section{Irodalom}

1. Toth T, Nagy V, Faludi R, Csanady M, Nemes A, Simor T, Forster T, Sepp R. The GIn1233ter mutation of the myosin binding protein $\mathrm{C}$ gene: Causative mutation or innocent polymorphism in patients with hypertrophic cardiomyopathy? INTERNATIONAL JOURNAL OF CARDIOLOGY 2011; 153(2): 216-219. DOI: 10.1016/j. ijcard.2011.09.062

2. Nemes A, Földeák D, Domsik P, Kalapos A, Sepp R, Borbényi Z, Forster T. Different patterns of left ventricular rotational mechanics in cardiac amyloidosis-results from the three-dimensional speckle-tracking echocardiographic MAGYAR-Path Study. QUANTITATIVE IMAGING IN MEDICINE AND SURGERY 2015; 5(6): 853857. DOI: 10.3978/j.issn.2223-4292.2015.11.07

3. Csanyi B, Popoiu A, Hategan L, Hegedus Z, Nagy V, Racz K, Hogye M, Saghy L, Ivanyi B, Csanady M, Forster T, Sepp R. Identification of two novel LAMP2 gene mutations in Danon disease. CANADIAN JOURNAL OF CARDIOLOGY 2016; 32(11): 1355.e231355.e30. DOI: 10.1016/j.cjca.2016.02.071 
4. Csányi B, Hategan L, Nagy V, Obál I, Varga ET, Borbás J, Tringer A, Eichler S, Forster T, Rolfs A, Sepp R. Identification of a Novel GLA Gene Mutation, p.lle239Met, in Fabry Disease with a Predominant Cardiac Phenotype. INTERNATIONAL HEART JOURNAL 2017; 58(3): 454-458. DOI: 10.1536/ihj.16-361

5. Sepp R, Hategan L, Bácsi A, Cseklye J, Környei L, Borbás J, Széll M, Forster T, Nagy I, Hegedüs Z. Timothy Syndrome 1 Genotype without Syndactyly and Major Extracardiac Manifestations. AMERICAN JOURNAL OF MEDICAL GENETICS PART A 2017; 173(3): 784-789. DOI: 10.1002/ajmg.a.38084

6. Maron MS, Olivotto I, Betocchi S, et al. Effect of left ventricular outflow tract obstruction on clinical outcome in hypertrophic cardiomyopathy. N Engl J Med 2003; 348: 295-303. DOI: 10.1056/NEJMoa021332

7. Ungi I, Palinkas A, Nemes A, Ungi T, Thury A, Sepp R, Horvath T, Forster T, Vegh A. Myocardial protection with enalaprilat in patients unresponsive to ischemic preconditioning during percutaneous coronary intervention. CANADIAN JOURNAL OF PHYSIOLOGY AND PHARMACOLOGY 2008; 86(12): 827-834. DOI: 10.1139/Y08-096 8. Olivotto I, Camici PG, Merlini PA, et al. Efficacy of Ranolazine in Patients With Symptomatic Hypertrophic Cardiomyopathy The RESTYLE-HCM randomized, Double-Blind, Placebo-Controlled Study. Circ Heart Fail 2018; 11: e004124. DOI: 10.1161/CIRCHEARTFAILURE.117.004124

9. Green EM, Wakimoto $\mathrm{H}$, Anderson $\mathrm{RL}$, et al. A small-molecule inhibitor of sarcomere contractility suppresses hypertrophic cardiomyopathy in mice. Science 2016; 351(6273): 617-21. doi: 10.1126/ science.aad3456. DOI: 10.1126/science.aad3456

10. Sigwart U. Non-surgical myocardial reduction for hypertrophic obstructive cardiomyopathy. Lancet 1995; 346: 211-14. DOI: 10.1016/S0140-6736(95)91267-3

11. Faber L, Seggewiss H, Welge D, et al. Echo-guided percutaneous septal ablation for symptomatic hypertrophic obstructive cardiomyopathy: 7 years of experience. Eur $\mathrm{J}$ Echocardiography 2004; 5: 347-355. DOI: 10.1016/j.euje.2004.01.001

12. Apró $D$, Lupkovics $G$, Motyovszki Á, et al. Alkohollal végzett myocardialis septum ablatio hypertrophias obstruktiv cardiomyopathiaban. Cardiologia Hungarica 2000; (Suppl 3): 63.

13. Sepp R, Pálinkás A, Rigopoulus A, Ungi I, Nagy V, Ruzsa Z, Horváth $\mathrm{T}$, Seggewiss $\mathrm{H}$, Csanády $\mathrm{M}$, Forster $\mathrm{T}$. Kontraszt echokardiográfia vezérelt perkután transzluminális septalis myocardium ablatio (PTSMA) hipertrófiás cardiomyopathiában: Contrast echocardiography guided percutaneous transluminal septal myocardium ablation (PTSMA) in hypertrophic cardiomyopathy. CARDIOLOGIA HUNGARICA 2007; 37(2): 113-119.

14. Elliott PM, Anastasakis A, Borger MA, et al. 2014 ESC Guidelines on diagnosis and management of hypertrophic cardiomyopathy: the Task Force for the Diagnosis and Management of Hypertrophic Cardiomyopathy of the European Society of Cardiology (ESC). Eur Heart J 2014; 35: 2733-2779. DOI 10.1093/eurheartj/ehu284

15. Gersh BJ, Maron BJ, Bonow RO, et al. 2011 ACCF/AHA Guideline for the Diagnosis and Treatment of Hypertrophic Cardiomyopathy: a report of the American College of Cardiology Foundation/ American Heart Association Task Force on Practice Guidelines. Developed in collaboration with the American Association for Thoracic Surgery, American Society of Echocardiography, American Society of Nuclear Cardiology, Heart Failure Society of America, Heart Rhythm Society, Society for Cardiovascular Angiography and Interventions, and Society of Thoracic Surgeons. J Am Coll Cardiol 2011; 58: e212-260. DOI: 10.1016/j.jacc.2011.06.011

16. Firoozi S, Elliott PM, Sharma S, et al. Septal myotomy-myectomy and transcoronary septal alcohol ablation in hypertrophic obstructive cardiomyopathy. A comparison of clinical, haemodynamic and exercise outcomes. European Heart Journal 2002; 23: 16171624. DOI: 10.1053/euhj.2002.3285
17. Gietzen FH, Leuner CJ, Raute-Kreinsen U, et al. Acute and long-term results after transcoronary ablation of septal hypertrophy (TASH). Catheter interventional treatment for hypertrophic obstructive cardiomyopathy. European Heart Journal 1999; 20: 1342-1354. DOI: 10.1053/euhj.1999.1520

18. Knight $\mathrm{C}$, Kurbaan AS, Seggewiss $\mathrm{H}$, et al. Nonsurgical septal reduction for hypertrophic obstructive cardiomyopathy: outcome in the first series of patients. Circulation 1997; 95: 2075-2081. DOI: 10.1161/01.cir.95.8.2075

19. Mazur W, Nagueh SF, Lakkis NM, et al. Regression of left ventricular hypertrophy after nonsurgical septal reduction therapy for hypertrophic obstructive cardiomyopathy. Circulation 2001; 103: 14921496. DOI: 10.1161/01.cir.103.11.1492

20. Boekstegers $P$, Steinbigler $P$, Molnar A, et al. Pressure-Guided Nonsurgical Myocardial Reduction Induced by Small Septal Infarctions in Hypertrophic Obstructive Cardiomyopathy. J Am Coll Cardiol 2001; 38: 846-853. DOI: 10.1016/s0735-1097(01)01412-7

21. Kim J-J, Lee CW, Park S-W, et al. Improvement in Exercise Capacity and Exercise Blood Pressure Response After Transcoronary Alcohol Ablation Therapy of Septal Hypertrophy in Hypertrophic Cardiomyopathy. Am J Cardiol 1999; 83: 1220-1223. DOI: 10.1016/ s0002-9149(99)00063-6

22. Lakkis NM, Nagueh SF, Dunn JK, Killip D, Spencer III WH. Nonsurgical Septal Reduction Therapy for Hypertrophic Obstructive Cardiomyopathy: One-Year Follow-up. J Am Coll Cardiol 2000; 36: 852-855. DOI: 10.1016/s0735-1097(00)00767-1

23. Rigopoulos A, Sepp R, Palinkas A, Ungi I, Kremastinos D Th, Seggewiss H. Alcohol septal ablation for hypertrophic obstructive cardiomyopathy: Collateral vessel communication between septal branches. INTERNATIONAL JOURNAL OF CARDIOLOGY 2006; 113(2): E67-E69. DOI: 10.1016/j.jijcard.2006.04.057

24. Chang SM, Lakkis NM, Franklin J, Spencer WH, 3rd, Nagueh SF. Predictors of outcome after alcohol septal ablation therapy in patients with hypertrophic obstructive cardiomyopathy. Circulation 2004; 109: 824-827. DOI: 10.1161/01.CIR.0000117089.99918.5A

25. Keren A, Poteckin M, Mazouz B, et al. Late in-hospital pressure gradient measurements improve prediction of long-term outcome of alcohol septal ablation in hypertrophic cardiomyopathy. Isr Med Assoc J 2007; 9: 239-242.

26. Sorajja P, Binder J, Nishimura RA, et al. Predictors of an optimal clinical outcome with alcohol septal ablation for obstructive hypertrophic cardiomyopathy. Catheter Cardiovasc Interv 2013; 81: E5867. DOI: $10.1002 / \mathrm{ccd} .24328$

27. Nemes A, Balazs E, Soliman OI, Sepp R, Csanady M, Forster $T$. Long-term prognostic value of coronary flow velocity reserve in patients with hypertrophic cardiomyopathy: 9-year follow-up results from SZEGED study. HEART AND VESSELS 2009; 24(5): 352-356. DOI: 10.1007/s00380-008-1131-0

28. Gavaller H, Sepp R, Csanady M, Forster T, Nemes A. Hypertrophic Cardiomyopathy Is Associated with Abnormal Echocardiographic Aortic Elastic Properties and Arteriograph-Derived Pulse-Wave Velocity. ECHOCARDIOGRAPHY-A JOURNAL OF CARDIOVASCULAR ULTRASOUND AND ALLIED TECHNIQUES 2011; 28(8): 848-852. DOI: 10.1111/j.1540-8175.2011.01469.x

29. Orosz A, Baczko I, Nagy V, Gavaller H, Csanady M, Forster T, Papp JG, Varro A, Lengyel C, Sepp R. Short-term beat-to-beat variability of the QT interval is increased and correlates with parameters of left ventricular hypertrophy in patients with hypertrophic cardiomyopathy. CANADIAN JOURNAL OF PHYSIOLOGY AND PHARMACOLOGY 2015; 93(9): 765-772. DOI: 10.1139/cjpp-2014-0526

30. Leonardi RA, Kransdorf EP, Simel DL, Wang A. Meta-analyses of septal reduction therapies for obstructive hypertrophic cardiomyopathy: comparative rates of overall mortality and sudden cardiac death after treatment. Circ Cardiovasc Interv 2010; 3(2): 97-104. DOI: 10.1161/CIRCINTERVENTIONS.109.916676 